\title{
Computer model for Vedavati ground water basin. Part 3. Irrigation potential
}

\author{
S VEDULA, C S RAMASESHA*, A ACHUTA RAO* and B SHYAM \\ PRASAD* \\ Department of Civil Engineering, Indian Institute of Science, Bangalore \\ 560012 , India
}

*Central Ground Water Board, 2, 36th Cross, 8th Block, Jayanagar, Bangalore 560082, India

MS received 6 March 1984; revised 23 August 1985

\begin{abstract}
An estimate of the irrigation potential over and above the existing utilisation was made based on the ground water potential in the Vedavati river basin. The estimate is based on assumed crops and cropping patterns as per existing practice in the various taluks of the basin. Irrigation potential was estimated talukwise based on the available ground water potential identified from the simulation study. It is estimated that 84,100 hectares of additional land can be brought under irrigation from ground water in the entire basin.
\end{abstract}

Keywords. Ground water; crop water requirements; irrigation potential; regional estimates.

\section{Introduction}

A major portion of the cropped area in the Vedavati river basin is rainfed cultivated at present. The net sown area is about $53 \%$ of the total geographical area of the basin. Out of the total sown area, approximately $6 \%$ is irrigated by canals, $10 \%$ by tanks and $7 \%$ by wells. At present, $10 \%$ of the ground water draft is being used for drinking purposes in the basin.

One of the objectives of the Vedavati river basin ground water modelling study is to determine the additional irrigation potential from the ground water resources of the basin over and above the present utilisation. Regional ground water simulation modelling (Part 2, Sridharan et al 1986) revealed that the average annual safe yield from the basin is $910 \mathrm{~m} \mathrm{cu} \mathrm{m}^{\dagger}$. The Central Ground Water Board estimates that, in addition, a quantity of $230 \mathrm{~m}$ cu m due to recharge from canals and tanks is available for local use annually. The present study is limited to estimating the irrigation potential corresponding to the ground water potential of $910 \mathrm{mcum}$ over the basin. The present paper

$+1 \mathrm{mcum}=10^{6} \mathrm{~m}^{3}$ 
estimates the talukwise irrigation potential consistent with the talukwise ground water potential and the cropping patterns (assumed based on the existing practice in each taluk), such that the irrigated areas will receive irrigation supply to the full requirement of the crops for their optimum growth.

Areas, presently under the command of canals or tanks, which may be receiving inadequate water supply as per the existing cropping patterns may however be considered, for augmentation of their present supplies, out of the $230 \mathrm{~m} \mathrm{cu} \mathrm{m}$ of annual recharge from the canals and tanks in the basin estimated by the Central Ground Water Board.

\section{Objective and scope}

The basin is predominantly a semiarid basin with scanty rainfall unevenly distributed and with limited irrigation facilities. The ground water potential is considered primarily for irrigation development. One of the primary goals of irrigation planning as recommended by the Second Irrigation Commission (Ministry of Irrigation and Power 1972 ) is to spread irrigation over as large an area as possible. The present study keeps in view these guidelines and estimates the maximum to which irrigation facilities may be extended in each taluk. Irrigation may be considered for presently rainfed cultivated areas or other cultivable land which is presently not being cultivated.

The objective of the study is to identify talukwise irrigation potential (over and above the existing level of irrigation from ground water) in the Vedavati river basin from the talukwise estimates of the safe yield based on assumption of crops and cropping patterns in the various taluks as per the existing practice. Thus the extent of additional area that can be brought under irrigation is determined for each taluk consistent with the availability of water and crop water requirements. The cropping pattern for future development of the ground water potential is assumed to be the same as at present because (i) predominantly semidry crops are grown in the basin and a radical change in the cropping pattern is unlikely to come about with increased ground water utilisation for irrigation, especially as irrigation does improve the crop yield to some extent even with the existing cropping pattern, and (ii) changing to new (water intensive) crops and new cropping patterns need additional investment which many farmers may find difficult to afford at the relatively low levels of land holdings in the basin.

\section{Ground water available for irrigation}

The ground water potential for additional development in the basin is given talukwise in table 1 . The number in the table against the name of a taluk was obtained by deducting the existing draft from the safe yield for the taluk obtained from the regional simulation model (Part 2). Out of this, the estimated use of ground water for drinking is to be deducted in order to arrive at the ground water availability for irrigation development. It was observed from the available data that nearly ten $\%$ of the existing ground water $\mathrm{draft}$ in the basin is being used for drinking and the rest for irrigation. It is assumed that the same proportion (i.e. $10 \%$ ) of use for drinking purposes holds good in the future also and the remaining ground water will be available for irrigation development. Thus, for the purpose of the present study, $90 \%$ of the ground water potential over and above 
Table 1. Ground water development potential of parts of the taluk area within Vedavati basin (excluding recharge from canals and tanks)

\begin{tabular}{lclr}
\hline \multicolumn{1}{c}{ Taluk } & $\begin{array}{c}\text { Development potential } \\
\text { (ha m/year) }\end{array}$ & Taluk & $\begin{array}{c}\text { Development potential } \\
\text { (ha m/year) }\end{array}$ \\
\hline Chickanayakanahalli & 2455 & Kadur & 5835 \\
Gubbi $_{\text {Koratagere }}^{\dagger}$ & 734 & Tarikere & 1790 \\
Pavagada $_{\text {Sira }}^{\dagger}$ & 26 & Channagiri & 67 \\
Tiptur $_{\text {Tumkur }}^{\dagger}$ & 763 & Arsikere & 3612 \\
Madhugiri & & Belur & 975 \\
Challakere & 458 & Hassan & 411 \\
Chitradurga $_{\text {Hiriyur }}$ & 897 & Gooty & 536 \\
Holalkere & 90 & Uravakonda & 385 \\
Hosadurga & 108 & Kalyandurg & 1202 \\
Jagalur & 372 & Rayadurg & 934 \\
Molakalmuru & 1867 & Madakasira & Nil \\
Chickamagalur & 1922 & Alur & 1503 \\
& 452 & Bellary & 2057 \\
& 4315 & Kudligi & 1858 \\
\hline
\end{tabular}

${ }^{\dagger}$ Part of the taluk is already overexploited. The estimate given is for the remaining area.

Note: In addition to the estimates in this table, 23,000 ha $\mathrm{m}$ of water are available annually from recharge from canals and tanks in the vicinity of these recharge sources (as estimated by the Central Ground Water Board).

the existing draft was considered available for irrigation development and is termed ground water development potential.

\section{Methodology used to determine irrigation potential}

Once the cropping pattern for each taluk was assumed as known, the monthly crop water requirements of each of the crops during its growing season were computed based on the guidelines given by the Ministry of Agriculture (1971). Estimates of crop consumptive use require data on measured or computed pan evaporation in the cropped region and the nature and duration of the crop under consideration. Monthly crop consumptive use was estimated for each of the crops in each of the taluks based on the available data in the various regions. The effective rainfall in each month was estimated based on the crop consumptive use and the average rainfall for the crop duration in that particular month. The net irrigation requirement is then given by the difference between the crop consumptive use and the effective rainfall. The field irrigation requirement was computed allowing for the on-farm losses for each of the crops. As the cropping pattern was known, the average annual field irrigation requirement for a taluk is given by the sum total of the field requirement of all the crops in that taluk for all the months in the year.

The irrigation potential (hectares) from ground water is computed by dividing the annual ground water potential (hectare metres) by the annual field irrigation requirement (hectare metres per hectare). The sum of these values for each taluk in the basin gives the total irrigation potential for the basin over and above the existing utilisation. 


\subsection{Crops and cropping patterns}

Keeping in view the type and extent of present cropping in the various taluks of the basin, specific crops and cropping patterns were indicated by the project team of the Central Ground Water Board for each of the taluks. Table 7 (referred to later) for example, gives the cropping pattern for the Chickanayakanahalli taluk. The table gives the name of the crop, the percent area of its cropping over the total cropped area and the growing season of the crop indicated by the months in which entries (of water requirement in metres) are made against the crop. The numbers in the table give monthly water requirements of each crop, the detailed computations of which are discussed in the subsequent section.

For purposes of estimating crop consumptive use, a total of 9 crops in the basin were considered in a year grown over three seasons, kharif, rabi and summer. The kharif crops were assumed to be sown on June 15, those in rabi on October 15 and those in summer on February 15. Table 2 gives the various crops considered and their growing periods.

\section{Estimation of crop water requirements}

Crop consumptive use and irrigation water requirements of the various proposed crops in the taluks were determined based on the guidelines by the Water Management Division of the Ministry of Agriculture (1971). Monthly crop consumptive use was obtained by multiplying the pan evaporation in the region by a suitable crop factor. The method requires either measured or computed pan evaporation for the specific regions under study.

\subsection{Evaporation}

Measurements of pan evaporation are available for limited lengths of time at 6 different stations, five of which are located in the basin and the sixth just outside it. Table 3 gives the locations of the stations and the length of the data available at the time of the present study.

Attempts were made to compute the evaporation at places where measured data were not available based on Christiansen's and other methods, but the lack of necessary

Table 2. Crops and their duration

\begin{tabular}{|c|c|c|c|}
\hline Crop & $\begin{array}{l}\text { Duration } \\
\text { (days) }\end{array}$ & Sowing date & $\begin{array}{l}\text { Crop factor* } \\
\text { for }\end{array}$ \\
\hline Paddy & 145 & 15 June & Rice \\
\hline $\begin{array}{l}\text { Ragi/jowar/maize/bajra/ } \\
\text { groundnut }\end{array}$ & 120 & 15 June & Maize (Ludhiana) \\
\hline Cotton & 240 & 15 June & Cotton \\
\hline Sugarcane & 365 & 15 June & Sugarcane \\
\hline Wheat & 110 & 15 October & Wheat (Ludhiana) \\
\hline Millet (ragi)/Bajra (short) & 105 & 15 October & Maize (Ludhiana) \\
\hline Gram/pulses & 110 & 15 October & Small vegetables \\
\hline Paddy & 145 & 15 February & Rice \\
\hline Pulses/vegetables & 110 & 15 February & Small vegetables \\
\hline
\end{tabular}

*Ref: Water Technology Centre (1977, p. 101). 
Table 3. Pan evaporation stations in the basin

\begin{tabular}{lll}
\hline Station & \multicolumn{1}{c}{$\begin{array}{c}\text { Length of } \\
\text { data }\end{array}$} & \multicolumn{1}{c}{ Source } \\
\hline Chickanayakanahalli & $1 \mathrm{yr}$ & CGWB Project \\
Hiriyur & $1 \mathrm{yr} 5 \mathrm{mth}$ & WRDO, Karnataka \\
Siddergadda & $5 \mathrm{yr}$ & CSIR, New Dethi \\
Siruguppa & $5 \mathrm{yr}$ & ICAR, New Delhi \\
Madhudi & $2 \mathrm{yr}$ & GWD, Andhra Pradesh \\
Gorur & $1 \frac{1}{2} \mathrm{yr}$ & WRDO, Karnataka \\
\hline
\end{tabular}

Abbreviations; CGWB-Central Ground Water Board; wRDo-Water Resources Development Organization; CSIR-Council of Scientific \& Industrial Research; ICAR-Indian Council of Agricultural Research; GWD-Ground Water Division.

climatological data at the desired locations precluded such an approach. It was finally decided to base the estimates of crop consumptive use on the measured values of pan evaporation alone by assuming the evaporation from each of the taluks in the basin to correspond to the measurements at one of the stations, identified as index station (in table 3), which bears close resemblance to the meteorological conditions in the taluk under consideration. Table 4 gives a list of the index stations and the taluks associated with it. The average monthly values of the index station were used for all the taluks listed against it. The monthly evaporation values at the index stations used in the study are listed in table 5.

\subsection{Crop factors}

Evapotranspiration is taken to be equal to the evaporation multiplied by the crop factor. For any given crop, the crop factor depends on its foliage characteristics, stage of growth, climate and geographical location. Because of the lack of such specific information for the present study the crop factors given in the Indian Agricultural Research Institute Monograph No. 4 on Water Requirement and Irrigation Management of Crops in India (Water Technology Centre 1977) were used (table 2).

Monthly values of consumptive use were computed based on the measured pan evaporation values and the appropriate crop factors for all the crops in all the taluks of the basin.

Table 4. Index stations for pan evaporation for taluks

\begin{tabular}{ll}
\hline Index station & \multicolumn{1}{c}{ Taluks } \\
\hline Chickanayakanahalli & $\begin{array}{l}\text { Chickanayakanahalli, Gubbi, Tiptur, Arasikere, Hosadurga, Tumkur, } \\
\text { Chickamagalur, Kadur, Tarikere (including Channagiri), Sandur, Kudligi }\end{array}$ \\
Hiriyur & Hiriyur, Sira, Challakere, Chitradurga, Jagalur, Molkalmuru, Holalkere \\
Siddergadda & Bellary, Gooty (including Uravakonda), Rayadurg \\
Siruguppa & Siruguppa, Alur, Adoni \\
Madhudi & Madakasira, Koratagere, Madhugiri, Pavagada, Kalyandurg \\
Gorur & Belur, Hassan
\end{tabular}


Table 5. Pan evaporation, measured (mm)

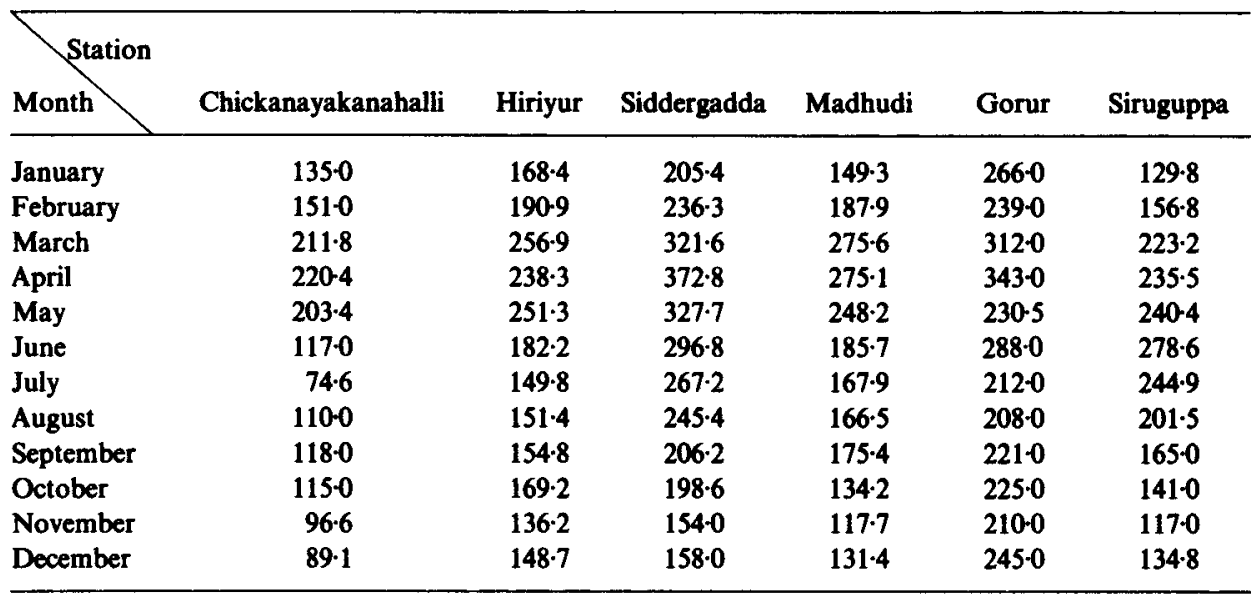

\subsection{Effective rainfall}

From the point of view of the water requirement of crops, the effective rainfall is defined as that part of the seasonal or annual rainfall which is useful for crop production at the site where it falls. In the present study, the average monthly effective rainfall was estimated from the consumptive use and mean monthly rainfall (as given by the Soil Conservation Service of the us Department of Agriculture) from table 4.21 of the IARI monograph (Water Technology Centre 1977). The estimates of the effective rainfall were based on a net depth of application of $75 \mathrm{~mm}$. The effective rainfall depends on the consumptive use and the rainfall itself. It may be noted here that the effective rainfall for a given consumptive use increases with increase in the rainfall, but is limited, at a certain value of the rainfall, to the value of the consumptive use. At and beyond this limit of rainfall, all the crop water need is met by the contribution from the rainfall itself and there is no need for irrigation. In all other cases, the crop needs irrigation to the extent of the difference between the consumptive use and the effective rainfall.

\subsection{Irrigation requirements}

The net irrigation requirement is the amount of irrigation water just required to bring the soil moisture content in the root zone depth of the crops to field capacity. Monthly values of the net irrigation requirement for any given crop (during its growing season) in any given region were obtained by deducting the effective rainfall values from the crop consumptive use. Rough estimates of the field losses at isolated locations in the basin, as indicated by the Central Ground Water Board, amount to about $30 \%$. The field irrigation requirement was computed based on the assumption of an average irrigation efficiency of $70 \%$ in all the taluks of the basin. Thus the field irrigation requirement was obtained by dividing the net irrigation requirement by 0.7 .

Table 6 shows the detailed computations of the field irrigation requirements of the kharif crop paddy in the taluk Chickanayakanahalli. The irrigation requirements of all the crops in all the taluks were computed based on the procedure adopted in table 6. The values in the last column giving the field irrigation requirement were transferred to the first row in table 7 , which gives the monthly water requirements of all the crops in 
Vedavati ground water basin. Part 3

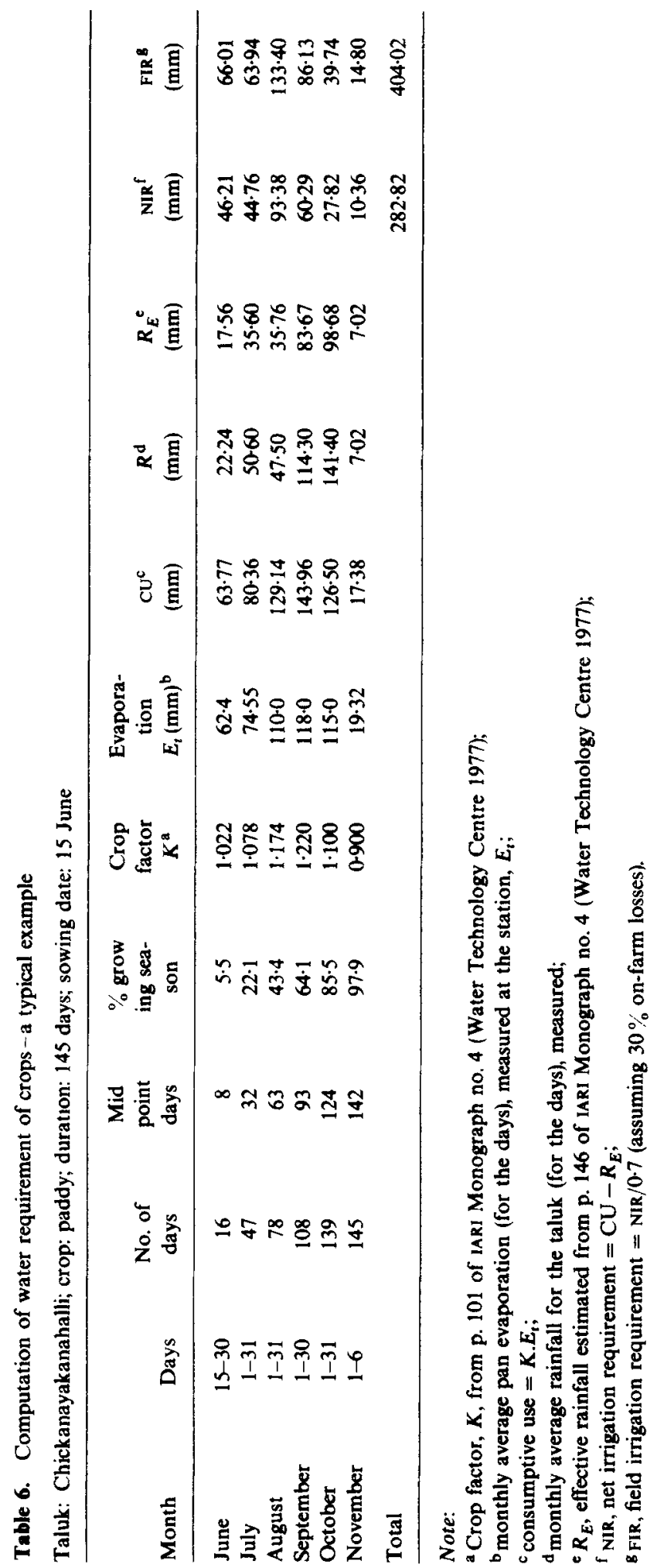




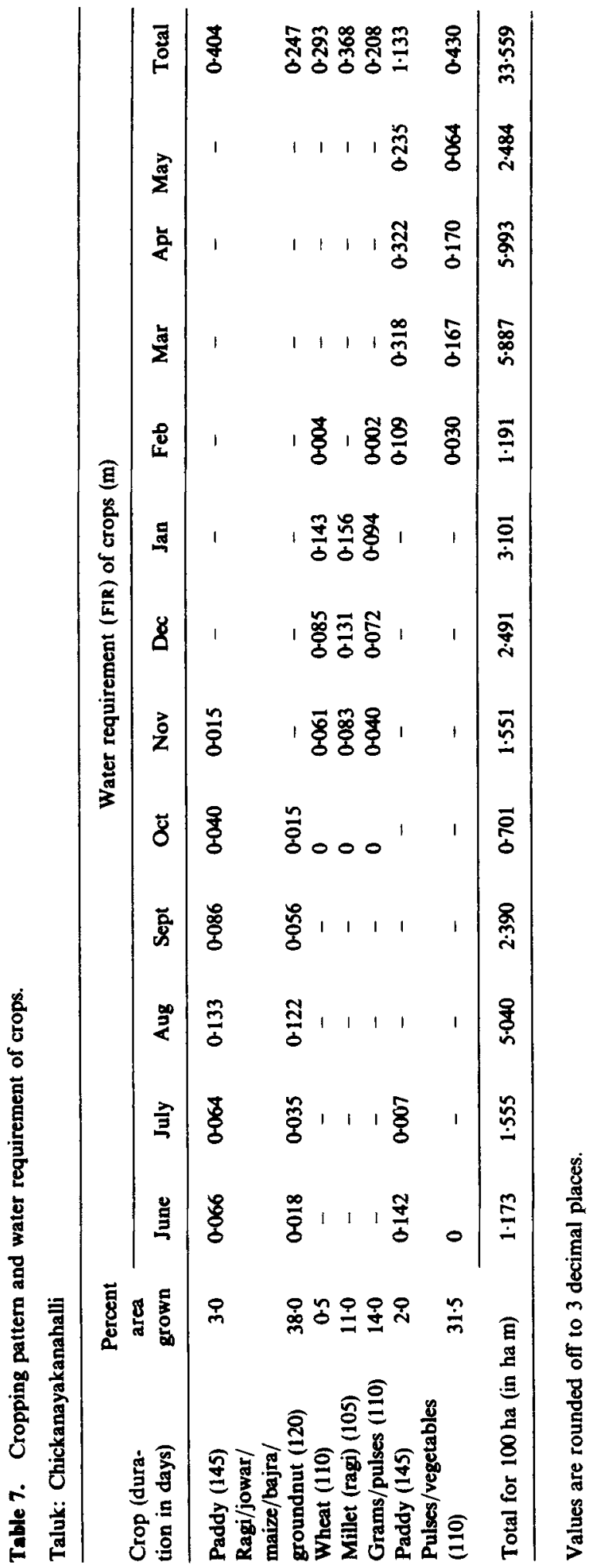


Chickanayakanahalli taluk along with the percent area of each crop proposed to be grown. Tables similar to table 7 were prepared for each of the 31 taluks in the basin.

\section{Irrigation potential}

Table 8 gives the additional irrigation potential (area) in each of the taluks under each of the districts covered by the basin. The table gives the taluk name, its geographical area in the basin, its development potential (for irrigation) in hectare meters (as determined from the regional simulation study), the annual water requirements for

Table 8. Ground water irrigation potential in the basin

\begin{tabular}{|c|c|c|c|c|}
\hline Taluk & $\begin{array}{c}\text { Geographic area } \\
\text { in basin } \\
\text { (ha) }\end{array}$ & $\begin{array}{l}\text { Ground water } \\
\text { irrigation } \\
\text { potential (GIP) } \\
\text { (ha m) }\end{array}$ & $\begin{array}{c}\text { Annual water } \\
\text { requirement } \\
\text { for irrigation (AWRI) } \\
\text { (ha } \mathrm{m} / 100 \mathrm{ha})\end{array}$ & $\begin{array}{c}\text { Irrigation } \\
\text { potential (IP) } \\
\text { IP = GIP/AWRI (ha) }\end{array}$ \\
\hline \multicolumn{5}{|l|}{ Tumkur district } \\
\hline Chickanayakanahalli & 114738 & 2210 & $33 \cdot 6$ & 6585 \\
\hline Gubbi & 42920 & 661 & $31 \cdot 6$ & 2091 \\
\hline Koratagere & 13156 & 23 & $60-3$ & 39 \\
\hline Madhugiri & 33935 & 97 & $44 \cdot 6$ & 218 \\
\hline Pavagada & 25603 & 687 & $51 \cdot 3$ & 1339 \\
\hline Sira & 155377 & 412 & $53 \cdot 7$ & 767 \\
\hline Tiptur & 26163 & 808 & $28 \cdot 5$ & 2838 \\
\hline \multirow[t]{2}{*}{ Tumkur } & 12562 & 81 & $30-2$ & 268 \\
\hline & & & & 14145 \\
\hline \multicolumn{5}{|l|}{ Chitradurga district } \\
\hline Challakere & 206219 & 335 & $73 \cdot 6$ & 455 \\
\hline Chitradurga & 126180 & 1681 & $59 \cdot 0$ & 2848 \\
\hline Hiriyur & 170093 & 1730 & $89 \cdot 0$ & 1943 \\
\hline Holalkere & 34010 & 407 & $74 \cdot 8$ & 544 \\
\hline Hosadurga & 142870 & 3883 & $54 \cdot 4$ & 7145 \\
\hline Jagalur & 42432 & 783 & $66 \cdot 5$ & 1177 \\
\hline \multirow[t]{2}{*}{ Molkalmuru } & 73859 & 871 & $75 \cdot 1$ & 1159 \\
\hline & & & & 15271 \\
\hline \multicolumn{5}{|l|}{ Chickamagalur district } \\
\hline Chickamagalur & 39282 & 1541 & $32 \cdot 7$ & 4717 \\
\hline Kadur & 132008 & 5251 & 30.9 & 17005 \\
\hline \multirow[t]{2}{*}{ Tarikere } & 32084 & 1611 & $35 \cdot 9$ & 4483 \\
\hline & & & & 26205 \\
\hline \multicolumn{5}{|l|}{ Hassan district } \\
\hline Arasikere & 110794 & 3251 & $28 \cdot 8$ & 11279 \\
\hline Belur & 24998 & 877 & $81 \cdot 0$ & 1083 \\
\hline \multirow[t]{2}{*}{ Hassan } & 10403 & 370 & $75 \cdot 1$ & 493 \\
\hline & & & & 12855 \\
\hline
\end{tabular}


Table 8. continued

\begin{tabular}{|c|c|c|c|c|}
\hline Taluk & $\begin{array}{c}\text { Geographic area } \\
\text { in basin } \\
\text { (ha) }\end{array}$ & $\begin{array}{l}\text { Ground water } \\
\text { irrigation } \\
\text { potential (GIP) } \\
\text { (ha } \mathrm{m} \text { ) }\end{array}$ & $\begin{array}{c}\text { Annual water } \\
\text { requirement } \\
\text { for irrigation ( } A \text { WRI) } \\
\text { (ha } m / 100 \text { ha) }\end{array}$ & $\begin{array}{c}\text { Irrigation } \\
\text { potential (IP) } \\
\text { IP = GIP/AWRI (ha) }\end{array}$ \\
\hline \multicolumn{5}{|c|}{ Bellary district } \\
\hline Bellary & 149054 & 1851 & 90.7 & 2041 \\
\hline Kudligi & 82950 & 1672 & $37 \cdot 3$ & 4483 \\
\hline Sandur & 34025 & 325 & $38 \cdot 2$ & 849 \\
\hline \multirow[t]{2}{*}{ Siruguppa } & 70323 & 1266 & 57.2 & 2213 \\
\hline & & & & 9586 \\
\hline \multicolumn{5}{|c|}{ Anantapur district } \\
\hline Gooty & 42914 & 483 & $81 \cdot 7$ & 591 \\
\hline Kalyandurg & 111292 & 1082 & $63 \cdot 2$ & 1712 \\
\hline Madakasira & 67186 & $*$ & 65.6 & $*$ \\
\hline Rayadurg & 166862 & 841 & 103.8 & 810 \\
\hline \multirow[t]{2}{*}{ Uravakonda } & 30835 & 347 & $65 \cdot 4$ & $530^{\dagger}$ \\
\hline & & & & 3643 \\
\hline \multicolumn{5}{|c|}{ Kurnool district } \\
\hline Adoni & 400 & 6 & 60.9 & $10^{t+}$ \\
\hline \multirow[t]{2}{*}{ Alur } & 92863 & 1347 & 60.9 & 2213 \\
\hline & & & & 2223 \\
\hline \multicolumn{5}{|c|}{ Shimoga district } \\
\hline \multirow[t]{3}{*}{ Channagiri } & 1200 & 60 & $67 \cdot 0$ & 168 \\
\hline & & & & 168 \\
\hline & & & Total for the basin & 84096 \\
\hline
\end{tabular}

${ }^{\dagger}$ Included in Gooty in figure $1{ }^{\dagger+}{ }^{\dagger}$ included in Alur in figure $1 ;{ }^{*}$ overexploited presently.

irrigation in ha $\mathrm{m} / 100$ ha determined from the estimates of crop water requirements, and the irrigation potential in hectares obtained by dividing the development potential by the water requirement. The district totals of the irrigation potential are also given in table 8. These estimates are intended for use in the irrigation development planning of the basin.

The total irrigation potential for the entire basin adds up to 84,096 hectares from the ground water aquifers in the basin over and above the existing level of ground water utilisation. Figure 1 shows the estimated irrigation potential for each of the taluks in the basin due to ground water.

\section{Conclusion}

A talukwise estimate of the irrigation potential from ground water in the Vedavati river basin was given. The estimate of the total irrigation potential of the basin from ground water is 84,100 hectares over and above the existing utilisation. This is in addition to the local potential for irrigation due to recharge from canals and tanks. 


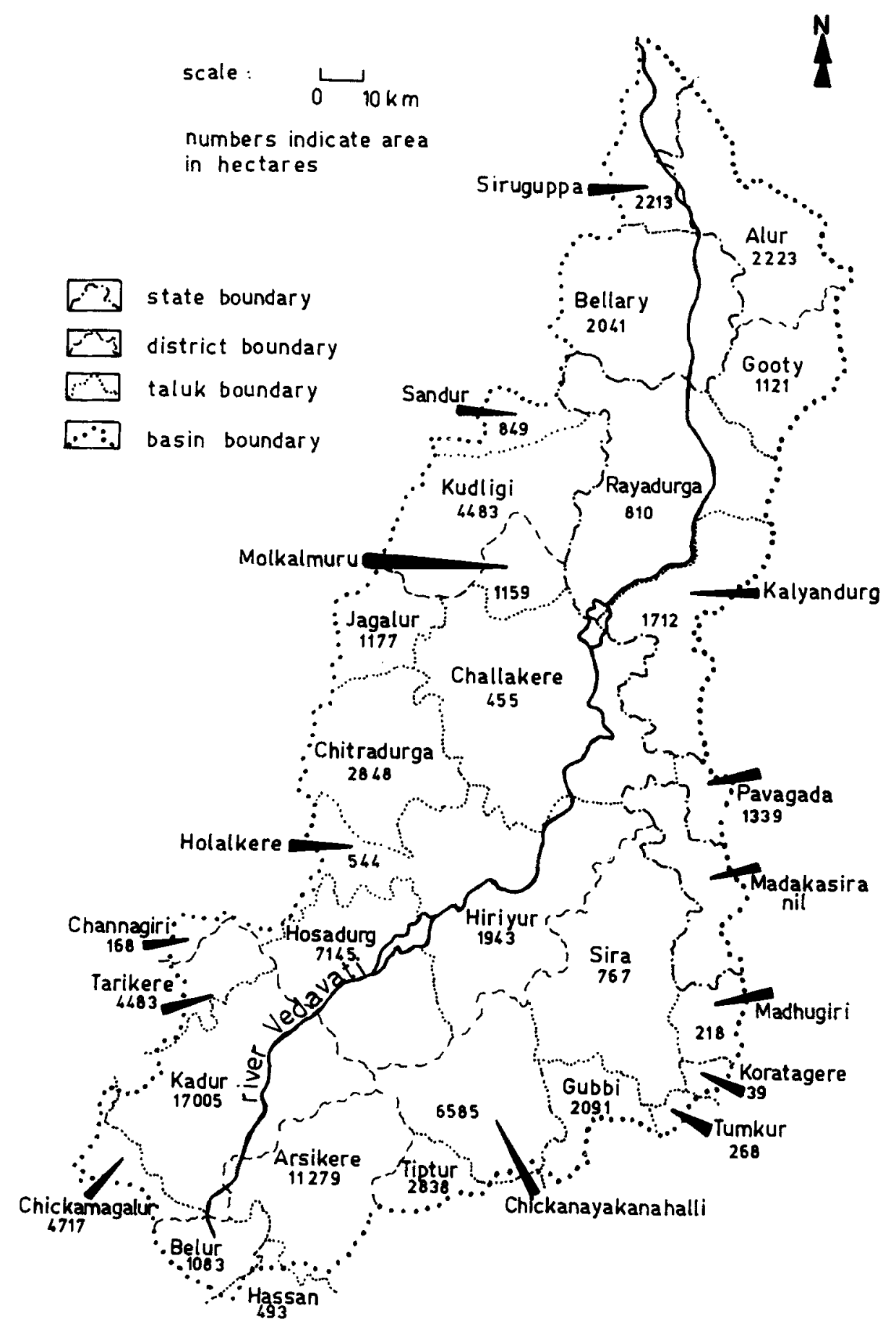

Figure 1. Talukwise irrigation potential (additional) in hectares. 


\section{References}

Ministry of Agriculture 1971 A guide for estimating irrigation water requirements, Water Management Division, Government of India, Technical Series 2

Ministry of Irrigation and Power 1972 Report of the Irrigation Commission, Government of India, Vol. 1 Sridharan K, Lakshmana Rao N S, Mohan Kumar M S, Ramesam V 1986 Sadhana 9: 43-55

Water Technology Centre 1977 Water Requirement and Irrigation Management of Crops in India, LAR1 Monograph no. 4, Indian Agricultural Research Institute 